\title{
The Factors Triggering Intimate Partnership Violence (IPV) Against Women in Patriarchy Society: A Case Study in Central Java, Indonesia
}

\author{
Margunani Margunani ${ }^{1}$ Inaya Sari Melati ${ }^{1 *}$ Anis Widyawati ${ }^{2}$ Tsabit Azinar Ahmad ${ }^{3}$ \\ ${ }^{1}$ Department of Economics Education, Universitas Negeri Semarang, Central Java 50229, Indonesia \\ ${ }^{2}$ Department of Law Science, Universitas Negeri Semarang, Central Java 50229, Indonesia \\ ${ }^{3}$ Department of History Education, Universitas Negeri Semarang, Central Java 50229, Indonesia \\ "Corresponding author. Email: inaya.sari@mail.unnes.ac.id
}

\begin{abstract}
This study aims to analyze the practices of Intimate Partnership Violence (IPV) against women in Semarang City as the capital of Central Java province in Indonesia and the factors that influence it. It is a qualitative research using interviews, focus group discussion, and documentation as data collection techniques. The sample was determined by the snowball-sampling technique with a total of 30 IPV survivors. The results showed that early marriage, alcohol or drugs consumption, trauma of abuse during childhood, husband's temperament, communication, husband domination, economic problems, and infidelity have an effect on IPV against women. Meanwhile, the level of education is not recorded has a contribution to trigger IPV against women. The high rate of IPV against women indicates the low level of public awareness of the position of women who are vulnerable and must be protected, especially in societies with a strong patriarchal culture such as in Semarang City. In this case, the role of community in all stages in overcoming violence is needed to reduce the high number of cases in Semarang City.
\end{abstract}

Keywords: IPV, Intimate Partner Violence, Domestic Violence, Violence, Women

\section{INTRODUCTION}

In Indonesia, 1 of 3 women aged 15-64 years experienced physical and or sexual violence during their life and about 1 in 10 women experienced it in the last 12 months [1]. Central Java, as one of provinces in Indonesia, accounts for the highest number of cases of violence against women. In the top 3 rankings of the highest cases of violence against women are Central Java $(2,913)$ then DKI Jakarta $(2,318)$ and East Java $(1,944)$ [2]. Cases of violence against women in Central Java have tended to increase in the last three years. In 2017 there were 1,869 cases, while in 2018 it increased to 1,883 cases of violence against women. Meanwhile, until 31 October 2019 there were 1,406 cases [3].

The problem of violence against women, especially the Intimate Partner Violence (IPV) is worse in Semarang City as the capital city of Central Java. Starting from 2012 [4] until 2020 [5], Semarang became the city with the highest cases of IPV in Central Java.

In 2013 the number of IPV cases against women in Semarang City in 2013 were recorded as many as 109 cases, consisting of 15 cases that are still in the process of being investigated, and 94 cases have been resolved with details of 62 cases that have been decided by the Semarang District
Court, there were 32 cases that were completed in mediation /non-litigation [6]. These cases include domestic violence, violence in dating, violence against children, rape, sexual abuse, and children in conflict with the law. The Legal Resources Center for Gender Justice and Human Rights Semarang, noted that throughout 2016 there were 496 cases of violence against women in Central Java and the most cases occurred in Semarang City with 199 cases [7].

On the other hand, efforts to strengthen women's empowerment in the perspective of the SDGs are revealed in various targets [8]; [9]. One of them is contained in Goal number 5 of the SDGs which stated "Empowering women and girls to take control of their bodies and lives is crucial for solving our biggest social and environmental crises" and Goal number 16 which stated "Educating and empowering women and communities, including ensuring access to voluntary family planning services, can help support peace and stability goals by increasing the foundation for stability". Specifically, the protection of women and girls from acts of violence is stated in Target 5.2, namely "Eliminating all forms of violence against all women and girls in public and private spheres, including sexual trafficking and other types of exploitation" and Target 5.3, namely "Eliminating all dangerous practices such as early 
marriage, forced marriage of children and female genital mutilation. "

World Health Organization (WHO) defines violence as the intentional use of physical force or power, threatened or actual, against oneself, another person, or against a group or community, that either results in or has a high likelihood of resulting in injury, death, psychological harm, maldevelopment, or deprivation [10]. As an effort to provide protection for women from violence, the Semarang City Government has a legal regulation namely Regional Regulation Number 5 of 2016 concerning the protection of women from violence. However, the relatively high phenomenon of IPV against women in Semarang City requires more concrete follow-up. One of them is by conducting a study analyzing the factors triggered IPV practices against women in Semarang City.

In 2011, a research analyzed some factors potentially drive IPV against women, including economic, psychological, cultural, and belief factors [11]; [12]. Even the local government has founded an official Non-Governmental Organization (NGO) named Seruni to provide integrated assistance for IPV survivors, including professional psychologist help and safe houses for the temporary place for them to "hide" from the persecutor [4], the curve of IPV in Semarang have not been flattening. Therefore, this study is needed to explore more about the stimulant factors of IPV to formulate more effective prevention and treatment programs which can be implemented to reduce the IPV rate in Semarang City in order to create a better gender equality as mentioned in one of SDG's goals.

This study comprises two research questions, shown below:

1. What are the factors triggered IPV against women in Semarang City?

2. How is the public awareness towards practices of IPV against women in Semarang City?

\section{LITERATURE REVIEW}

\subsection{The Feminist Theory}

Based on the Feminist Theory, violence against women is caused by gender inequality at the social level [13]. The more unequal women and men are in society, the more likely it is that men will commit violence against women. The status of women is a complex multidimensional concept. Gender inequality, or patriarchy, including ideological issues (beliefs, norms, and values about the status and role of women in society) and structural issues (women's access and position in social institutions) [14]. In addition, ideological and structural imbalances occur in various dimensions, including political, economic, and social dimensions [15].

The key limitation of the theory of violence against women in the household is that male dominance is seen as the only contributing variable rather than seeing it as a central organizing feature. Bonnie Fox argued that violence against women are "the most poorly theorized of all aspects of gender inequality [16]. Therefore, Hunnicut tries to add a different perception in studying cases of violence against women, namely by focusing on the external environment of women [17]. Hunnicut categorizes social orders that give more power to men as dominators, including: (a) the patriarchal system at the macro level, namely: bureaucracy, government, market and religion; and (b) the patriarchal system at the micro level, namely: interaction, family, organization, partner behavior patterns.

\subsection{IPV Against Women}

According to article 1 of the 1993 UN Declaration, the term violence against women is defined as "any act of genderbased violence that results in, or is likely to result in physical, sexual or psychological harm or suffering to women, including threats of such acts, coercion or arbitrary deprivation of liberty, whether occurs in public or in private life". Violence against women is any form of action that causes suffering to women and affects women's physical and psychological health. The 2019 annual record published by Komnas Perempuan states 3 categories of how women experience violence, namely the private / personal category or commonly known as domestic violence, the public or community category, and the state category.

Violence against women in this study is limited to violence that occurs within the family or household using the terminology Intimate Partner Violence (IPV). The factors that will be studied to explain the occurrence of violence against women in the household refer to the first two factors determined by WHO, namely individual factors and relationship factors [10]. Individual factors include young age, low level of education, drugs and/or alcohol consumption, experience of childhood abuse, acceptance of violence, and personality disorders. Relationship factors include conflict or dissatisfaction in a relationship, male domination in the family, economic problems, infidelity, and gaps in education.

\section{RESEARCH METHOD}

This research was conducted in Semarang City from April to September 2020. Data was collected at the respondent's residence or at the NGO Seruni office, depending on the respondent's willingness. The population of this study is based on data from the Semarang City Women and Children Empowerment Service website amounting to 142 people. The sample was determined using snowball sampling technique because not all victims were willing to be interviewed about the violence they experienced, related to comfort, privacy and the sense of trauma they experienced. The research team in collaboration with the NGO Seruni succeeded in collecting 30 samples of IPV survivors. The data collection techniques used in the implementation of this study were interviews, focus group discussions, and documentation. The method of data analysis includes analyzing interviews' transcripts, data reduction, analysis, data interpretation and data triangulation. 


\section{RESULTS AND DISCUSSION}

\subsection{Overview of IPV Practices against Women Cases of Violence against Women and in Semarang City}

Cases of IPV against women in Central Java province for the past 5 years are still unsettling. Based on the types of violence experienced by women, the Central Java Regional Police Office classified the types of violence into eight groups, namely (1) physical violence; (2) psychological violence; (3) sexual violence; (4) delinquency; (5) human trafficking; (6) exploitation; (7) domestic violence; and (8) others.

From the total 164 cases of violence in 2020 in Semarang City, 145 victims or $88.41 \%$ of them were women [5]. However, the number of reports submitted to the local Police Office of Semarang City was far less than that number. The number of reports of violence against women in Semarang City in the last 5 years has been dominated by domestic violence with the number of cases from 20152019 respectively $31,29,8,3$, and 11 reports, while only 1 report on cases of delinquency occurred in 2019 in Ngaliyan District. In 2020, from the same source, the number of incoming reports was only 27 reports.

The disparity in the number of cases of violence recorded in the NGO Seruni and those reported at the Semarang Police Office illustrates that law enforcement in these cases is not directly proportional to the high number. This is because making a report to the police requires at least two pieces of evidence and two witnesses. Meanwhile, in many cases, the victim was unable to show evidence and witnesses so that the case could not be proceeded to court. In addition, in the community in Semarang City, reporting acts of violence committed by husbands against their wives to the police are still considered taboo, due to strict patriarchal culture which indirectly tolerates these acts as normal.

\subsection{Factors Triggering IPV Against Women in Semarang City}

\subsubsection{Early Marriage}

Quantitatively, the research data shows that 7 out of 30 IPV survivors are in early married. This means that $23.33 \%$ of IPV survivors are the perpetrators of this marriage. This also proves the World Health Organization, which estimates that more than $30 \%$ of women worldwide have experienced violence by their husbands both sexually and physically [18].

As many as 93\% of IPV survivors felt that they were mature enough when they decided to get married, as well as their perception of their partners, $83 \%$ of respondents considered their partners were also mature enough to get married. This is reinforced by data on the age of respondents where the average age of women victims of violence is 22 years old at marriage, with the youngest age 13 years, the oldest age 36 years and a standard error of 0.75 . The average age of 22 years has passed the limits of the provisions of Law Number 16 of 2019 concerning marriage (16 years), however some respondents did not meet the minimum limit of the National Health Board (20 years) in relation to reproductive readiness. IPV survivors with age at marriage less than 20 years are as many as 7 people.

On the other hand, the average age of the IPV survivors at marriage was 23 years with the youngest 13 years old, the oldest age 36 years old and a standard error of 0.76 . The average age of 23 years has passed the limits of the provisions of Law Number 16 of 2019 concerning marriage (19 years), while the Health Office does not specify a specific age regarding reproductive readiness for men.

Qualitatively, the details of the case experienced by one of the IPV survivors who had an early marriage can be described as follows.

The youngest survivor who reported violence with a marriage age of 2 years was R17. Survivor R17 got married at the age of 13 with a peer who was 14 years old because she became pregnant outside of marriage. Survivor R17 had to experience physical violence by her husband and her own parents. The husband committed physical violence when there was a disagreement, while R17's father also committed physical violence if the victim did not obey his orders (including the order to be married because he was pregnant). In addition, the victim experienced psychological violence committed by her in-laws in the form of harsh words accusing her of ruining the future of her school husband and damaging the family's good name. Survivor R17 also experienced social violence in the form of being ostracized by the community because he was considered a woman who could not take care of herself because she was known to be pregnant outside of marriage. In addition, Survivor R17 also experienced economic neglect because her husband was still in school and not yet working.

\subsubsection{Low Education Level}

The data collected from the results of this study showed that $53.33 \%$ of IPV survivors had the same level of education as their husbands. In addition, there were $26.67 \%$ of IPV survivors who had a higher education level than their husbands, and $20 \%$ of IPV survivors who had an education level below their husbands. Based on these data, it is not confirmed that the gap in education level is one of the causes of violence against women.

The results of this study also reinforce the notion that the high level of education of women does not guarantee that they will escape violent practices. On the other hand, the high level of male education is not necessarily in line with the high level of their emotional intelligence. Husbands can commit violence regardless of the level of education and work they have [19]. This is evidenced by the fact that 3 $(10 \%)$ of the 30 cases of domestic violence were committed by men with higher education at the level of Bachelor's. There is insufficient evidence to conclude that domestic 
violence will decrease as the level of education for both women and men increases.

\subsubsection{Alcohol and (or) Drugs Consumption}

Only 1 in 30 IPV survivors admitted to frequently consuming alcohol, namely Survivor R1 who was married at the age of 18 (mentioned in the discussion of early marriage) and worked as a prostitute due to threats from her husband, while the rest stated that they never consumed alcohol. On the other hand, 13 out of 30 husbands who commit domestic violence admit to never consuming alcohol. However, the remaining 17 out of 30 husbands who committed domestic violence admitted that they often or sometimes consume alcohol. This means that $57 \%$ of perpetrators of domestic violence are exposed to alcohol with frequent and occasional intensity.

In terms of drug use, 20 out of 30 IPV survivors admit that they have never routinely consumed certain drugs. The remaining 10 out of 30 women consume drugs regularly, mostly headaches (7 respondents), stomach drugs (2 respondents) and high blood pressure (1 respondent). Meanwhile, from the husband's side, as the perpetrator of domestic violence, 23 out of 30 perpetrators never regularly consumed certain drugs. Some consume drugs for certain diseases ( 3 people) and 4 out of 30 IPV survivors are known to routinely consume drugs such as sedatives and stamina enhancers. Perpetrators who consume these sedatives are also known to frequently consume alcohol. Therefore, it can be concluded that alcohol consumption and exacerbated by drugs can lead to IPV practices.

\subsubsection{Trauma of Abuse during Childhood}

The research data shows that only 5 out of 30 IPV survivors have experienced childhood abuse by their parents / relatives. On the other hand, experiences of abuse as a child were mostly experienced by husbands who were perpetrators of IPV. The abuse experienced by the husband varied, ranging from abuse by his own parents, siblings, to playmates. However, there is one perpetrator who has never experienced violence from his parents, but has been treated too spoiled by his parents. This case occurred in Respondent R17 who married at the age of 13 because she was pregnant with her peer.

However, the general trend that occurs based on the data of this study shows that 15 out of 30 husbands who commit IPV have experienced incidents of abuse in the past. Therefore, it is concluded that the experience of abuse in childhood can spur domestic violence for women (wives). These results reinforce the research [19] which shows that more than half of husbands have experienced violence in childhood which is able to influence the level of violence on the pretext that corporal punishment is a way to discipline wives.

\subsubsection{Husband's Temperamental Character}

When conflicts occur, most wives as victims choose to act passively, such as being silent, crying, giving in or avoiding by going to their room or going to their parents' house. Although there were also answers from respondents such as fighting or retaliating, only 5 respondents said they had the courage to fight their husbands when there was an argument or violence. On the other hand, most husbands who commit violence are reactive when an argue occurs with their wives by hitting, yelling, saying harsh words, saying intimidating things, and breaking things. Based on the data, there were only 3 husbands who did not commit violence at all and chose to remain silent. Even husbands who choose to leave their homes, some are still violent before leaving the house.

\subsubsection{Communication Barrier}

As many as 19 out of 30 IPV survivors admitted that they never communicated well during their marriage. This is because if there are problems in the household, the husband (or wife) puts forward emotions resulting in worse quarrel. Some survivors also mentioned that husbands are more comfortable telling their problems to their families or other parties than their wife, it makes communication between husband and wife is not well established. As many as 7 out of 30 survivors answered that they only communicate when it is related to certain topics such as child and economic issues. Only 1 in 30 survivors claimed to be able to communicate well with her husband, namely R6, but that did not prevent him from physical violence and infidelity. Based on the domination of answers from the IPV survivors and supported by information obtained from the Semarang Police Office regarding communication as the main problem that causes domestic violence, it is concluded that poor communication between husband and wife can trigger violence against women.

\subsubsection{Men's Dominance}

There is only 1 in 30 IPV survivors who claim their husband always discuss everything every time they have to make a decision related to family life. The remaining 29 IPV survivors stated that their husband does not care enough with his wife's opinion and seldom or even never invite them to discuss anything during their marriage. Mostly, survivors complained about husband's decision in using his money. Survivors think their husband often waste the money to buy unimportant goods / property / pets or else without considering another more important need in their family. As many as 3 IPV survivors complained about their husbands who were difficult to communicate with, they often do not have any idea where their husband had gone and when they will return home. Another example of husband domination is that the husband often forces his will and the will of his family on his wife. Based on these data, it can be concluded that the dominance of the husband can lead to IPV practices. 


\subsubsection{Financial Issue}

As many as 16 out of 30 IPV survivors admitted experiencing domestic violence due to economic problems. Mostly, the husband did not have a concern to provide money for household needs and when the wife asked for money, they got angry and did physical and (or) psychological violence. In other case, it is founded that the husband does not work or does not have a permanent job so that he asked for money from his wife and when the wife cannot provide the money he needs, he committed violence. There is also a case of survivor who experienced human trafficking in order to get money to meet family needs as described in the section 4.2.1.

The lower the family economy, the more potential increases the risk of violence against wives [20]. Economic problems are common and fundamental to domestic violence. This is because humans depend on money to fulfill their needs. When the income received is not enough to buy food or pay bills, it is possible to have an argument that leads to violence by the husband against the wife.

\subsubsection{Infidelity}

As many as 19 out of 30 IPV survivors caught their husband having an affair and ended up getting violent acts from him. Domestic violence that befell the wife in this case occurs due to several things, including: (1) the wife tries to make the husband admit that the husband has cheated on him and the husband does not accept being accused of cheating so that he becomes emotional and commits violence, (2) the wife catches the husband's affair red-handed and the husband covers his shame by committing violence, (3) the wife demands the same rights as the husband's affair, especially in terms of spending money for household needs. Generally, women victims of domestic violence experience not only physical violence, but also psychological, sexual, social, economic neglect and human trafficking. The types of domestic violence experienced by respondents can be observed in Figure 1. below.

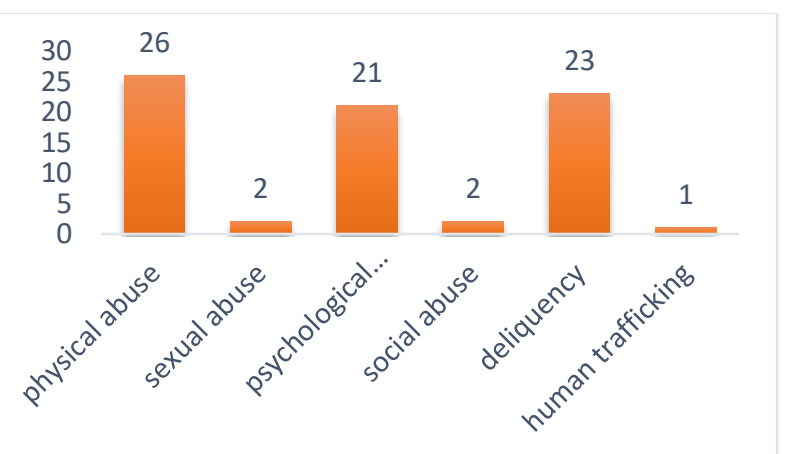

Figure 1. Number of Women Victims of Domestic Violence by Type of Violence

\subsection{The Community Concern for IPV Against Women in Semarang City}

The high percentage of IPV survivors shows how low public awareness of the importance of respecting the human rights of others, especially women. This is a serious threat to women and needs serious attention and handling not only by the government, but also all levels of society. Protecting women means protecting and saving the sustainability of future generations [21]. IPV Cases in Semarang City reached 140 cases in 2020. Public concern of it is still low, both in prevention, handling, and recovery of IPV survivors. Socio-cultural condition in Semarang City which still hold strict patriarchy leads to violence which often reflects social or economic disparities between community groups. A number of studies have identified a link between gender inequality and levels of violence against women [22]. Jacobson identifies several social factors that may create conditions that lead to violence [23], including: (1) society's permissive attitude towards violence against women; (2) men's control in decision-making and restrictions on women's freedoms; (3) the rigid identities and roles of men and women in society; (4) relations between people that demean women; (5) slum and densely populated environment and (6) exposure to violence.

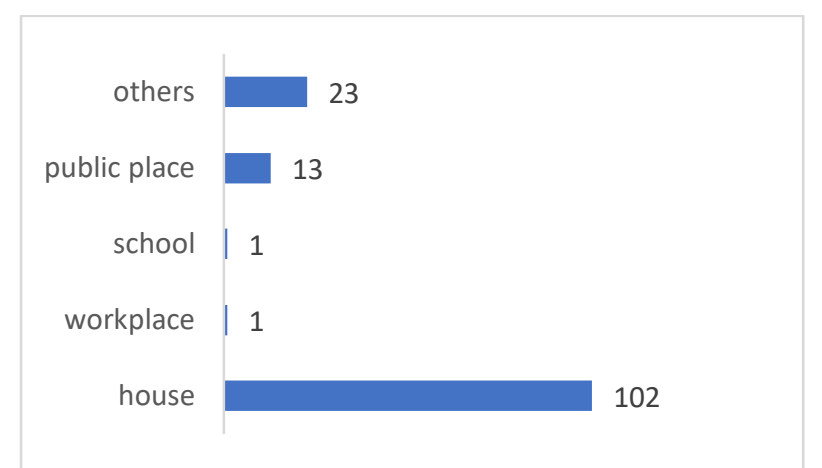

Figure 2. The Location where Violence against Women Takes Place

The data from Figure 2 indicate that violence predominantly occurs in households which should be the center of affection in order to form a humanist society. Several public spaces also contributed to a high number of incidents of violence. It has become increasingly clear that public awareness of the vulnerable position of women which should be protected is still low.

The dominance of solving problems of violence is still in the normative role of the government. The cultural approach that is actually also needed to deal with violence against children and women is still rare. The considerable distance between the community and victims of violence causes obstacles to the process which necessitates an interaction between the two. The role of the community in all stages of combating violence is needed to reduce the high number of cases in Semarang City. 


\section{CONCLUSION}

The rate of IPV against women in Central Java, especially in the Semarang City tends to increase from year to year, so it is necessary to strengthen awareness from various parties in society. The factors that influence violence against women include early marriage, use of alcohol and drugs, past violence exposure, husband's character and communication barrier, men's dominance, financial issues, infidelity can lead to IPV against women. Meanwhile, it cannot be decided whether the husband / wife's education level can lead to violence against women in the household. The finding of this study implicates that patriarchal values greatly affect the pattern of relationships in the household. However, this cannot be a justification for a husband to commit violence against his wife. Primary prevention efforts must be directed at improving the existing social order [24]. Society needs to aware that violence, whatever its form and to whoever the violence is committed, is a criminal act that cannot be justified for whatever reasons. Social campaigns and direct participation programs are important things to do in a massive and coordinated manner in order to change people's perspective, shift the culture to be more friendly to women, and in the long-run, change the economic and political structure. Evaluation of policies that can be carried out by the government regarding the protection of women, namely strengthening of protection institutions in various regional strata to fostering and supervising communities to prevent IPV against women practices.

This study is limited to the number of IPV survivors who are willing to be interviewed and the distribution of their location had not been represented all regions in Semarang City. It is recommended for the next study to improve the number of participants and to add other parties as participants, such as the husbands (the perpetrator of IPV), family member, neighbors, and local government to provide more objective point of views about IPV practices in Semarang City.

\section{ACKNOWLEDGMENT}

This work was supported by Universitas Negeri Semarang and The Ministry of Education and Culture, Indonesia.

\section{REFERENCES}

[1] Badan Pusat Statistik. (2016). Potret Awal Tujuan Pembangunan Berkelanjutan (Sustainable Development Goals) di Indonesia. Badan Pusat Statistik.

[2] Perempuan, K. (2019). Catatan Kekerasan Terhadap Perempuan Tahun 2018. Jakarta: Komnas Perempuan.
[3] Insetyonoto. (2019). Kekerasan terhadap Perempuan dan Anak di Jateng Meningkat. News retrieved from https://www.gatra.com/detail/news/459244/hukum/keke rasan-pada-perempuan-dan-anak-di-jateng-meningkat

[4] Irawati, M. A. (2015). Pelayanan Terpadu Korban Kekerasan Terhadap Perempuan Di Kota Semarang. Jurnal Natapraja: Kajian Ilmu Administrasi Negara, $3(2)$.

[5] Data Kekerasan Kota Semarang Periode 1 Januari 31 Desember 2020. Retrieved from: http://ppt.dp3a. semarangkota.go.id/

[6] Semarang, L. W. K. (2013). LKPJ Walikota Semarang Akhir Tahun Anggaran 2018. Laporan Pertanggungjawaban Wali Kota Semarang, 499-505.

[7] Hardiyanti, M., Purwanti, A., \& Wijaningsih, D. (2018). Optimalisasi Penanganan Korban Kekerasan Terhadap Perempuan dan Anak Melalui Lembaga Layanan Rujukan (Rumah Aman) di Kota Semarang. Diponegoro Law Journal, 7(2), 122-136.

[8] Fredman, S., Kuosmanen, J., \& Campbell, M. (2016). Transformative Equality: Making the Sustainable Development Goals Work for Women. Ethics and International Affairs, 30(2), 177-187. https://doi.org/ $10.1017 / \mathrm{S} 089267941600006 \mathrm{X}$

[9] Garcia-Moreno, C., \& Amin, A. (2016). The sustainable development goals, violence and women's and children's health. Bulletin of the World Health Organization, 94(5), 396. DOI: 10.2471/BLT.16.172205

[10] Siegler, M., \& Rogers Jr, S. O. (Eds.). (2020). Violence, trauma, and trauma surgery: Ethical issues, interventions, and innovations. Springer Nature.

[11] Kartiko, R. (2011). Analisis Kriminologi Terhadap Faktor-Faktor Yang Mendorong Kekerasan Terhadap Perempuan (Studi Terhadap Kejahatan Yang Disertai Dengan Kekerasan Terhadap Perempuan Di Wilayah Hukum Polres Semarang Selatan). Universitas Negeri Semarang.

[12] Anantri, K. M. (2017). Analisis Faktor-Faktor yang Mempengaruhi Remaja Putri terhadap Perilaku Kekerasan dalam Pacaran di SMA "X" Kota Semarang. Jurnal Kesehatan Masyarakat (e-Journal), 3(3), 908917.

[13] Bograd, M. (1988). How battered women and abusive men account for domestic violence: Excuses, justifications, or explanations? 
[14] Dobash, R. E., \& Dobash, R. (1979). Violence against wives: A case against the patriarchy (pp. 179206). New York: Free Press

[15] Bradley, K., \& Khor, D. (1993). Toward an Integration of Theory and Research on the Status of Women. Gender \& Society, 7(3), 347-378

[16] Fox, B. (1993). On violent men and female victims: a comment on DeKeseredy and Kelly. Canadian Journal of Sociology, 18, 320-324.

[17] Hunnicutt, G. (2009). Varieties of patriarchy and violence against women: Resurrecting "patriarchy" as a theoretical tool. Violence against women, 15(5), 553-573. https://doi.org/10.1177/1077801208331246

[18] Ellsberg, M., Arango, D. J., Morton, M., Gennari, F., Kiplesund, S., Contreras, M., \& Watts, C. (2015). Prevention of violence against women and girls: what does the evidence say? The Lancet, 385(9977), 15551566. https://doi.org/10.1016/S0140-6736(14)61703-7

[19] Albadayneh, Diab M. (2012). Violence Against Women in Jordan. Journal of Family Violence. 27: 369379. DOI: 10.1007/s10896-012-9429-1

[20] Cho, Hyunkag. (2012). Racial differences in the prevalence of intimate partner violence against women and associated factors. Journal of Interpersonal Violence. 27(2): 344-363. DOI: 10.1177/0886260511416469

[21] De Jonge Oudraat, C. (2011). Women and war: Power and protection in the 21st century. US Institute of Peace Press.

[22] Jewkes, R., Flood, M., \& Lang, J. (2015). From work with men and boys to changes of social norms and reduction of inequities in gender relations: a conceptual shift in prevention of violence against women and girls. The Lancet, 385(9977), 1580-1589. https://doi.org/ 10.1016/S0140-6736(14)61683-4

[23] Chen, P., Voisin, D. R., \& Jacobson, K. C. (2016). Community violence exposure and adolescent delinquency: Examining a spectrum of promotive factors. Youth \& Society, 48(1), 33-57. https://doi.org/ $10.1177 / 0044118 X 13475827$

[24] Salter, M. (2016). 'Real men don't hit women': Constructing masculinity in the prevention of violence against women. Australian \& New Zealand Journal of Criminology, 49(4), 463-479. https://doi.org/10.1177/ 0004865815587031 